\title{
ECODESIGN FROM HIGH SCHOOL TO BACHELOR LEVEL: A FRENCH CASE STUDY
}

\author{
Perpignan, Catherine (1); Robin, Vincent (2); Baouch, Yacine (1); Eynard, Benoit (1) \\ 1: Universite de Technologie de Compiegne; 2: Université de Bordeaux
}

\begin{abstract}
Nowadays, our society needs that an awareness be made about our impact on the planet. Many more or less alarmist reports tell us that there is a need to change our consumption patterns, production and energy consumption ... One of the main axes to achieve these goals is education. Thus integrating sustainable development into the skills of future engineers is an essential challenge but above all a necessity to modify and reduce our impact on the environment and to allow a global understanding of the complexity of our society. For this, companies must also evolve. Some will do so in a strategy of greening their image, others will have to comply with the various regulations of their sector of activity and a final category of these companies will use this opportunity as a vector of innovation. Each at their level will make a contribution, the integration over time of new sustainability skills within their staff will expand their action. In this article, we will focus our study on the integration of ecodesign in the industry and the impact that this generates in terms of skills to acquire, values to evolve and knowledge to master.
\end{abstract}

Keywords: Ecodesign, Education, Case study, Sustainability

\section{Contact:}

Perpignan, Catherine

Universite de Technologie de Compiegne

Mechanical Engineering

France

catherine.perpignan@u-bordeaux.fr 


\section{INTRODUCTION}

In France the latest record on the law on energy transition for green growth voted in 2015 which aims is to reduce GHG emissions by $75 \%$ in 2050 is not convincing. It is also one of the objectives of the $9^{\text {th }}$ (Industry, Innovation and Infrastructure) and 12th (Responsible Consumption and Production) Sustainable Development Goal edited by United Nations. Therefore, Industries (but other sectors too) have to contribute to achievement of this objective and it is increasingly necessary for them to change design and manufacturing strategies of their products (Vezzoli et al., 2015).

In the 90s Ecodesign emerged, objective was minimized the environmental impact of a product by focusing on early phases of its lifecycle and particularly on the design phase (ISO 14006: 2011). Nowadays more and more industrials and academic researchers (McAloone \& Pigosso, 2017) think that it should take a more prominent place in business strategies and to evolve towards taking into account the other parameters of sustainable development (economic and social pillars) (Dekonink et al., 2016). This implies changing the business of the company from an economic logic to an environmental transition one. That obliges to make evolve state of mind of decisions-makers, managers and engineers by enriching their training with sustainability values and new skills. Indeed, it seems that one way to achieve this goal is educating. That's why our research goal is to propose a model to answer the question: "how to define an appropriate training for the acquisition of new skills and values related to eco-design in this new context?"

Our hypothesis, in accordance with the OECD Education 2030 framework, is that we have to establish the correlation between knowledges, skills, attitudes and values (Figure 1) to develop adapted training programs for future engineers.

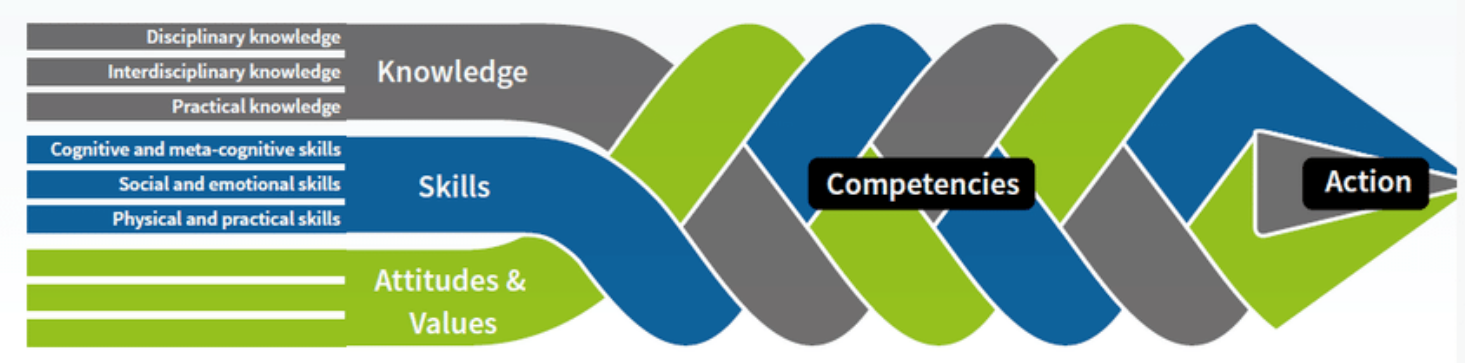

Figure 1. The Future of Education and Skills: OECD Education 2030 Framework

Such a hypothesis leads to develop a reflection on:

- The knowledges, skill, values and attitudes:

○ what knowledges, skills, values and attitudes are needed to work with students to foster the acquisition of specific knowledges to eco-design?

- The temporality and the curricula:

- When knowledges, skills, values and attitudes must appear in school curricula?

- Are knowledges, skills, values and attitudes integrated in a training continuum from high-school to university or engineering schools the most relevant solution?

Our research methodology to develop our reflection is composed with different steps and our progression is describe on Figure 2. 


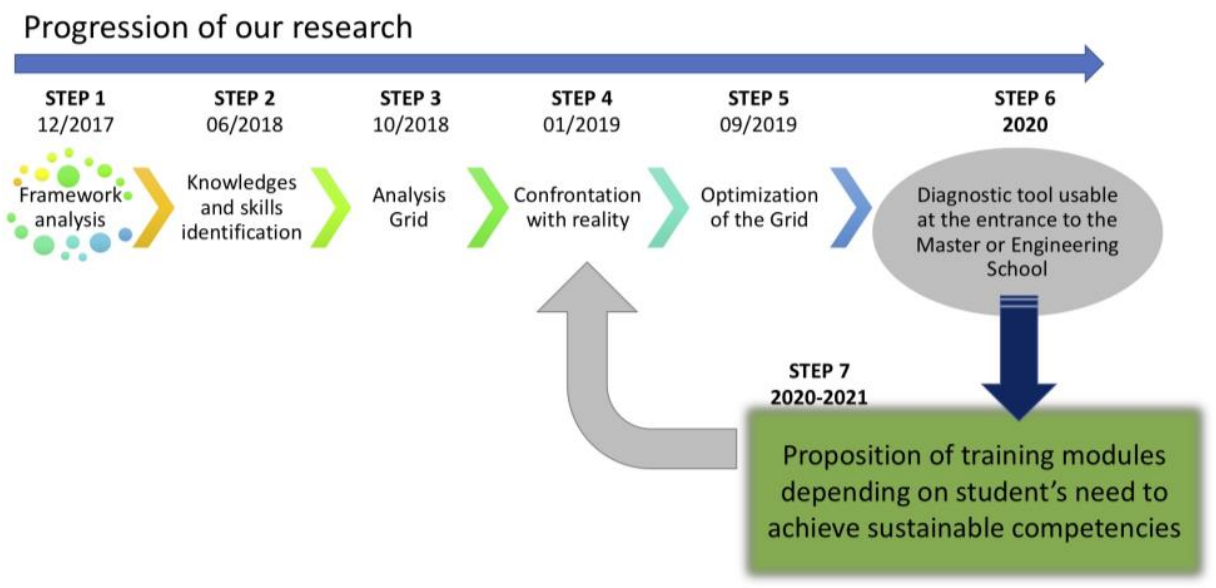

Figure 2. Steps of the research methodology

In this paper, first section concerns the three first steps of our research methodology and we present a literature review concerning eco-design (definitions and evolutions). The second section is a case study of eco-design integration in different technological French curricula that corresponds to the step "confrontation with reality". Objective is to identify the effective place of sustainable development and eco-design in the technological training courses. Third section is a more precise analysis curricula to make appear if knowledge, skills, attitudes and values that are theoretically important to train future engineers are worked during engineers' school curriculum. Finally, we present our analysis grid and discuss about the relevance and feasibility of building a training continuum for environmental transition from high school to Bachelor.

\section{STEPS 1-2. ECO-DESIGN: WHAT KNOWLEGDE AND SKILLS ARE NEEDED?}

Many experts agree that to eco-design, strong technical knowledges in engineering design are needed but it is also important to be able to identify issues raised in other areas impacting the social and economic component of the business. Thus, it is not enough to handle tools or methods to meet the challenges of this period of environmental transition (Bergea et al., 2005). It is also necessary to be able to reflect on longterm impacts and to open up mind on all the areas affected by the choice of a technological solution. A first analysis of the literature has revealed that the current training in eco-design consists more of a superposition of layers in which knowledges and skills are accumulated (De Vere et al., 2010). Correlation is rarely made and the continuity between cycles study does not exist. It becomes necessary to interconnect the two, so that future engineers will be in possession of all the key skills to solve technical and societal issues that will arise to them. We need a holistic sustainable thinking strategy, so students can engage with different stakeholders and develop skills to contextualise appropriate choices (Andrews and Soares, 2017). Nowadays, transversal skills are being developed among young pupils who are no longer exploited elsewhere. Our goal is to rely on disciplinary foundations that lead to the training of specialist engineer with the ability to identify the impact of their decision-making on other fields. For this, it is necessary to develop both disciplinary knowledges of design, skills and abilities. Then students will combine them with transversal skills and knowledges broadening the scope of assessment of selected technological solutions.

\subsection{What kind of engineers' competencies for sustainability?}

First what is the main aim of ecodesign? Are we only reduce our actions on the environmental impact like the ISO define it or must we act on others fields? Obviously, the ISO definition is no longer enough for companies. Indeed, a transition towards "Circular Economy and the integration of social innovation into sustainability initiatives can be observed, which leads to strategic and holistic sustainability considerations in the design of complex systems" (McAloone and Pigosso, 2017). Many industries which move toward an implementation of ecodesign strategy search to identify different levers to involve all the actors of the company (Bhamra, 2004). It means that future engineers will need in addition to the environmental parameters take into account the social and economic impacts involved in the design process. So new skills are necessary. One of the main axes to achieve these objectives is education. 
Thus, integrating sustainable development into the skills of future engineers is a key challenge but above all a necessity to change and reduce our environmental impact and to allow a global understanding of the complexity of our society. Some researchers have identified some requirements in skills and competencies in engineering courses which permit to enter in a sustainable way. The table 1 shows some examples of kind of skills that can be developed during an engineering curriculum.

\section{Table 1. Competencies and skills for an engineering curriculum}

\begin{tabular}{|c|c|c|c|}
\hline $\begin{array}{c}\text { Aoudia, Al-Qahsil } \\
2015 \\
\end{array}$ & Kamp, 2014 & $\begin{array}{c}\text { Wiek et al } \\
2011\end{array}$ & Andrews,Soares, 2017 \\
\hline \multirow[t]{2}{*}{$\begin{array}{l}\text { Strong design } \\
\text { capabilities }\end{array}$} & $\begin{array}{l}\text { Rigour of Engineering } \\
\text { Knowledge }\end{array}$ & & $\begin{array}{l}\text { appreciate the importance of } \\
\text { environmental, social and } \\
\text { political contexts }\end{array}$ \\
\hline & $\begin{array}{l}\text { Critical Thinking and } \\
\text { Unstructured Problem } \\
\text { Solving }\end{array}$ & & $\begin{array}{l}\text { develop a high level of self- } \\
\text { reflection at a personal and } \\
\text { professional level }\end{array}$ \\
\hline \multirow[t]{2}{*}{$\begin{array}{l}\text { Define, analyse, } \\
\text { model and solve } \\
\text { problems }\end{array}$} & $\begin{array}{l}\text { Interdisciplinary and } \\
\text { Systems Thinking }\end{array}$ & $\begin{array}{l}\text { System thinking } \\
\text { competence }\end{array}$ & $\begin{array}{l}\text { solve or ameliorate real life } \\
\text { problems through employing } \\
\text { holistic approach }\end{array}$ \\
\hline & $\begin{array}{l}\text { Imagination, Creativity, } \\
\text { Initiative }\end{array}$ & $\begin{array}{l}\text { Anticipatory } \\
\text { competence }\end{array}$ & $\begin{array}{l}\text { think creatively, holistically, and } \\
\text { systemically and make critical } \\
\text { judgements on issues }\end{array}$ \\
\hline \multirow{4}{*}{$\begin{array}{l}\text { Teamworking and } \\
\text { communication } \\
\text { skills }\end{array}$} & $\begin{array}{l}\text { Communication and } \\
\text { Collaboration }\end{array}$ & $\begin{array}{l}\text { Interpersonal } \\
\text { competence }\end{array}$ & $\begin{array}{l}\text { work collaboratively and work } \\
\text { in interdisciplinary teams }\end{array}$ \\
\hline & $\begin{array}{l}\text { Global Mind-Set: } \\
\text { Diversity and Mobility }\end{array}$ & $\begin{array}{l}\text { Normative } \\
\text { competence }\end{array}$ & $\begin{array}{l}\text { apply theory to practice and vice } \\
\text { versa }\end{array}$ \\
\hline & $\begin{array}{l}\text { Ambitious study } \\
\text { culture: Student } \\
\text { Engagement and } \\
\text { Professional Learning } \\
\text { Community }\end{array}$ & & $\begin{array}{l}\text { understand, critically evaluate } \\
\text { and adopt thoughtfully } \\
\text { sustainability values }\end{array}$ \\
\hline & $\begin{array}{l}\text { Employability and } \\
\text { Lifelong Learning }\end{array}$ & $\begin{array}{l}\text { Strategic } \\
\text { competence }\end{array}$ & $\begin{array}{l}\text { initiate and manage change that } \\
\text { supports sustainable } \\
\text { development in personal, } \\
\text { institutional and social contexts }\end{array}$ \\
\hline
\end{tabular}

In the same context, the Swedish Higher Education Act has determined what students must acquire in an engineering training taking into account sustainability. Pargman and Eriksson (2015) have categorized 4 sorts of ability to:

- develop and design products, processes and systems while taking into account the circumstances and needs of individuals and the targets for economically, socially and ecologically sustainable development set by the community;

- make assessments informed by relevant disciplinary, social and ethical aspects;

- demonstrate insight into the possibilities and limitations of technology, its role in society and the responsibility of the individual for how it is used;

- identify the need for further knowledge and undertake.

In these 4 abilities we can found: disciplinary knowledges, strategic views (social and economic aspects), system thinking, critical thinking, building values and ethics, strategic competencies. As Segalas et al (2012) demonstrate engineers need to explore cognitive (knowledge and understanding) and metacognitive (skills and abilities and attitudes) domains during their training. The analysis of these different papers allowed to identify transversal skills which must be mastered to enter in a sustainable way (Figure 3).

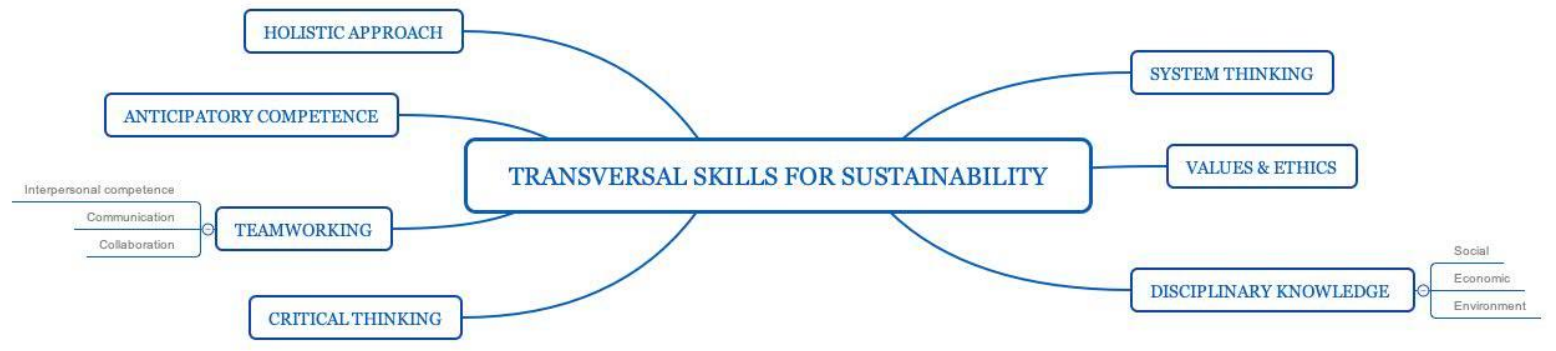

Figure 3. Mapping of competencies to enter in a sustainable project 
For our research, we have chosen to investigate and to focus on the eco-design principle. We will try to define what kind of competencies future engineers will need (Vallet et al., 2013) to integrate sustainability in a professional context and how is it possible to combine them with eco-design cursus.

\subsection{Ecodesign: skills to cross}

Ecodesign is based on two strong concepts namely the identification of environmental impacts and life cycle assessment. To be able to integrate these two concepts, the literature shows that it is necessary to have transversal skills in which will be integrated the disciplinary skills necessary to answer the problems posed in a context of sustainable development (Brones, 2017). Thus according to Boks (2006), we could distinguish the eco-design "hard side" and "soft side". On the one hand it integrates theoretical knowledge in design engineering in terms of so-called "hard" such as environmental assessment and the handling of the associated theoretical tools, and on the other hand "soft" which include non-technical skills. Pezesheki et al (2012) distinguish four areas for their eco-design and sustainability model for higher education:

1. Core science;

2. Facilitative strategies, for instance tool development;

3. canonical eco-design philosophy, i.e. decision-making processes;

4. conceptual knowledge and paradigms shift.

This reading of skills must also be cross-checked with the needs of companies in this field. Some companies note that "engineers should have a better understanding of the natural resource constraints facing our world, as well as economic constraints and opportunities for sustainable development" (Hanning et al., 2012). The companies surveyed also mentioned "communication problems concerning the problems of sustainable development and the difficulties encountered by their employees to understand the link between their work and sustainable development". The questions were not about the disciplinary knowledge that is acquired, but about the transdisciplinary skills or related to a global consideration of sustainable development in everyday practices. Thus, the current challenges for companies wanting to engage in an eco-design or sustainable approach is to act on: knowledge, business strategy, interpersonal skills, collaboration and management. (Dekonink et al., 2016).

\section{STEP 3-4. ECODESIGN EDUCATION IN FRANCE AND ANALYSIS GRID}

In the French context, many ways for students to become an engineer exist (Figure 4).

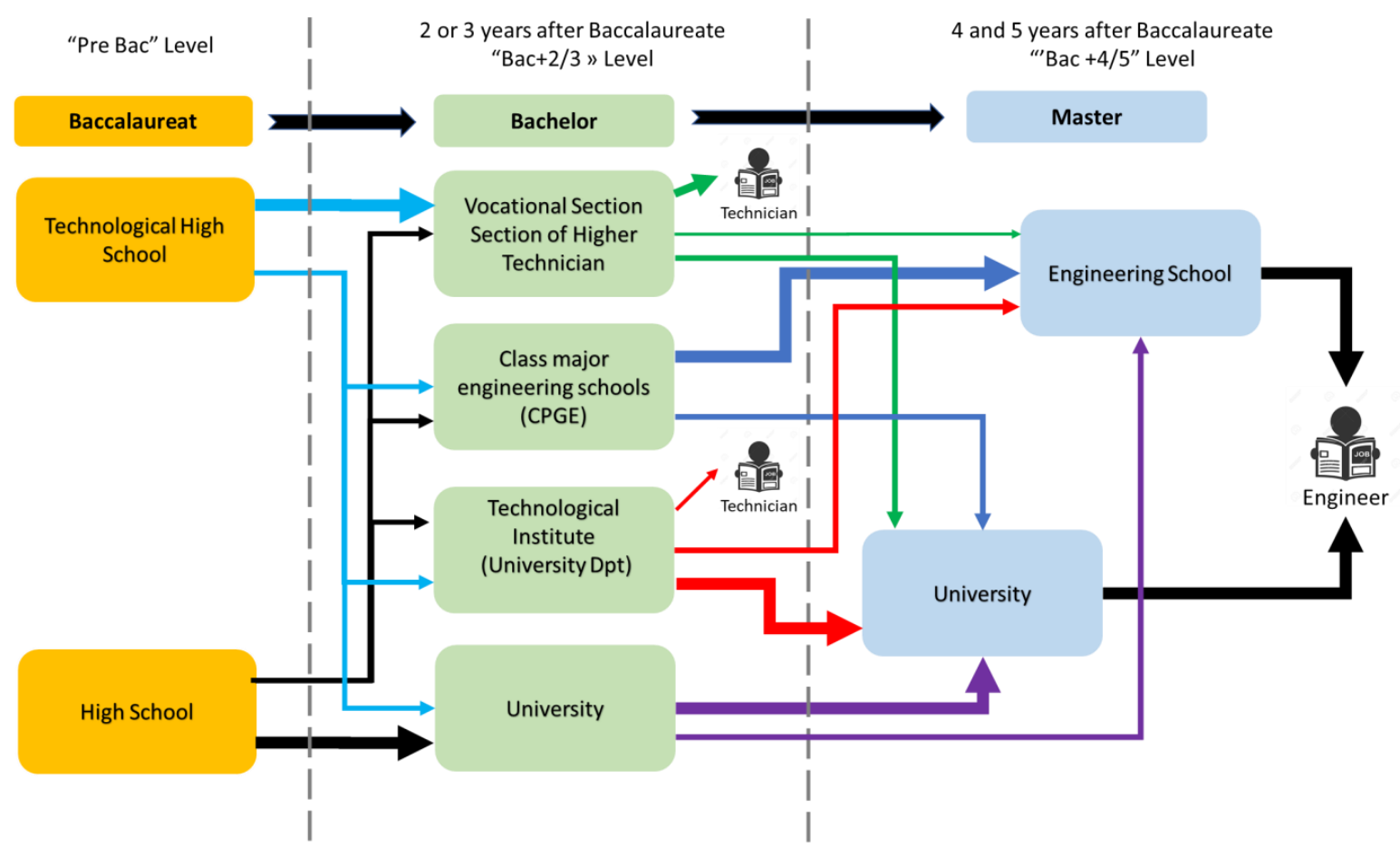

Figure 4. School path to become an engineer in France 
The first step is the high school in which students can choose the technological way or the "classic" one. Normally, both of them allow students, after obtaining "Baccalaureate" diploma at the end of high school to follow courses at university, in vocational curricula, in technological institutes or class for major engineering schools (CPGE). Nevertheless, experience puts in evidence that this second step is harder for students from technological ways particularly in university. After two- or three-years students obtain different diplomas that allow us applying the entrance examinations of engineering schools (French "Grandes Ecoles d'Ingénieurs"), it is the last step to get an access to these schools. In the figure 4 arrow's thickness indicates the proportion of students in the different sectors

\subsection{Analysis of secondary and high school curricula}

\subsubsection{Secondary school}

At secondary school students have begun to work skills related to solving technical problems taking into account environmental parameters. The purely disciplinary contributions related to eco-design are relatively weak. The emphasis is more on "soft skills" (Harris and Rodgers, 2008) like: teamworking, getting organized, listening to each other, learning to communicate with others with report and oral presentation. These skills will then enable future students to understand problems to be solved by taking into account wider perimeters that can be impacted by their solution. These soft skills associated with less vertical and more participative teaching practices such as project-based learning or inquiry-based learning should allow to develop other essential skills related to sustainable development: an ethic and a system of values, systemic thinking, a complex thought, forward thinking and anticipation.

\subsubsection{High school}

At the end of secondary school students can choose several ways: the general high school or the technological high school. In general, high school, they do not really deal with technical subjects but more with traditional disciplinaries like literature, mathematics, history, sciences... Sustainable development will be taught, but during courses like economy or history not with a technical point of view. On the other way, in technological high school, students can follow a specific training in technology and sustainable development. In this curriculum, learning is focused on the teaching of a global engineering culture with basics for developing and managing various kind of complex technological products or systems. As regards technological training, sustainable development appears with the notion of eco-design. It is presented as a concept that integrates multiple aspects of complex product and system design and environmental issues. The goal is to create sustainable solutions that meet human needs and desires. In 2019, a new French educational framework will put even more emphasis on issues related to sustainability. The technological section will be more anchored in the spirit of STEM (Science, Technology, Engineering, Mathematics), which have contributed since the 90s to decompartmentalize the disciplines to favor the resolution of complex problems highlighting the necessary consideration of all interfering parameters on a system (Roberts, 2012). Thus, new integration of the teaching for scientific and technical disciplines should favor the multiple technology integration of systems in all its dimensions (technical, social, economic or environmental). Eco-design should be considered not only as technical aspects for its implementation, but should broaden students' thinking about the other economic and social parameters that affect their choice of design. The objective is to gradually lead them to take into account more broadly the issues related to their technological choice. In 2017, according to a national education report, only $6.8 \%$ of students in France followed such curricula. On this first part relating to the path in the secondary school of students, we realize that working on the concept of eco-design itself is very complicated. On the one hand students can in high school follow different paths with different education standards that are under the authority of the French Ministry of Education and that leaves us no latitude. On the other hand, the training of teachers must be taken into account. Indeed, they often have not received initial training in this area (the average age in French national education is 43 years old). Teachers are sometimes withdrawn on this theme for lack of knowledge and in front of them they have young people sensitized very early on these topics with some strong values concerning the environment. Following this same logic, we pursued our research by focusing our study on the technical tracks followed by students after obtaining their baccalaureate's degree. On figure 4, we can notice that a 
significant number of students choose the university path to achieve an engineer degree. That the reason, we will focus our study on university training offers.

\subsection{Assessment of technological Bachelor}

A specificity in higher education in France is the "Instituts Universitaires de Technologie" (IUT). It is an internal institute of a university which provides an initial and continuous training intended to prepare for the professional position of technical management in specific industrial sectors of the production and after sales, of the research and development or services. We focused our research more specifically on the IUT of Mechanical and Production Engineering. We analyzed the national curriculum which is the reference for all IUTs offering this training. In this framework, competency related to eco-design is considered as a basic skill of the future holder of the diploma, that he can be brought to use during the activities: of engineering design, production planning, management of basic manufacturing systems. These skills and knowledge related to eco-design are principally focused on measuring environmental impacts and driving life cycle analysis, it is present during the 4 semesters of the training. For the rest of our study, it will be important to compare this reference with real practices to determine the skills actually achieved in this field by students.

\subsection{Analysis of vocational Bachelor}

Concerning the STS (Sections de Techniciens Supérieurs / Higher Technician curricula), our study has for the moment focused on the Industrial Product Design program, whose new framework was deployed during the autumn of 2018. In this program, we count 12 occurrences of the term "sustainable development", 24 occurrences for "eco-design" and "life cycle". Students in these courses are expected to be able to: "take into account and optimize the design with regard to the requirements of the product life cycle". Thus, in the 14 business competencies expected to deliver the Industrial Products Design Technician curricula, competency 12 caught our attention: "integrating eco-design in the design of a product". In this competency, the identification of the knowledge of environmental standards, the principles of sustainable development and environmental decision support tools are clearly identified. This demonstrates an evolution of the need to take into account the environmental parameter in the function of designing. But like for the IUT we need to check what is really taught to students.

\subsection{First Analysis of Engineering Science Bachelor}

Our last analysis focus on bachelor courses at University. The study is more complex for Bachelor cursus because the universities are not subject to a repository or an educational program. It means that each university can build its own training offer. But before we lead a closer inquiry in the next months, an overview of different bachelor curriculum was made. The main conclusion of this research is that few Bachelor degree in Engineering Sciences offer modules related to ecodesign or sustainability. They are mainly focus on disciplinary courses (mechanical engineering, automatic control, electronics, computer engineering...). So, it seems interesting to deepen this line of work as do many European universities (Olsten et al., 2018), (Pérez-Foguet et al., 2019), (Svanström et al., 2012), (Cassais et al., 2012).

\subsection{Synthesis: proposal of an assessment grid}

To have a global vision of the place of eco-design in national education standards, we need to use a specific tool that will allow us to make an inventory of what is taught in the different technological curricula. In a previous article (Perpignan et al., 2018) we carried out a synthesis of some elements of courses in eco-design and sustainable development in French curricula from secondary school to university. We have established an assessment grid to identify which knowledges and skills are delivered in the various French training courses from secondary school to bachelor. This grid shows us that "hard" eco-design contents are more or less addressed in the different paths. The following education levels can therefore rely on these elements to build their training curriculum while proceeding upstream to an analysis of the levels of acquisition of these skills. On the other hand, at the level of transversal skills, there is a lack of investment in the pre- and post-"baccalaureate" level. With such a representation, we show how all dimensions of sustainability are addressed (or not) across education programs. We also highlight complexity to cover all dimensions of sustainability with the existing programs and possible evolutions of eco-design trainings in a more global sustainable vision closed to companies' expectations. We used this grid for a theoretical assessment which have 
considered the French education framework and in a practical context. It means that we have to discuss with training actors to identify what level is achieved in sustainability in this different context. After the analysis of the literature and the French engineering framework from high to bachelor, we categorized skills in 4 themes and different sub-domains that we can identify in the training offer in different universities (Table 2):

- Technical disciplinary skills,

- Eco-design specificity (skills and knowledge),

- Economic and social skills for sustainability,

- Transversal skills for sustainability.

Table 2. Main skills in eco-design in French curricula

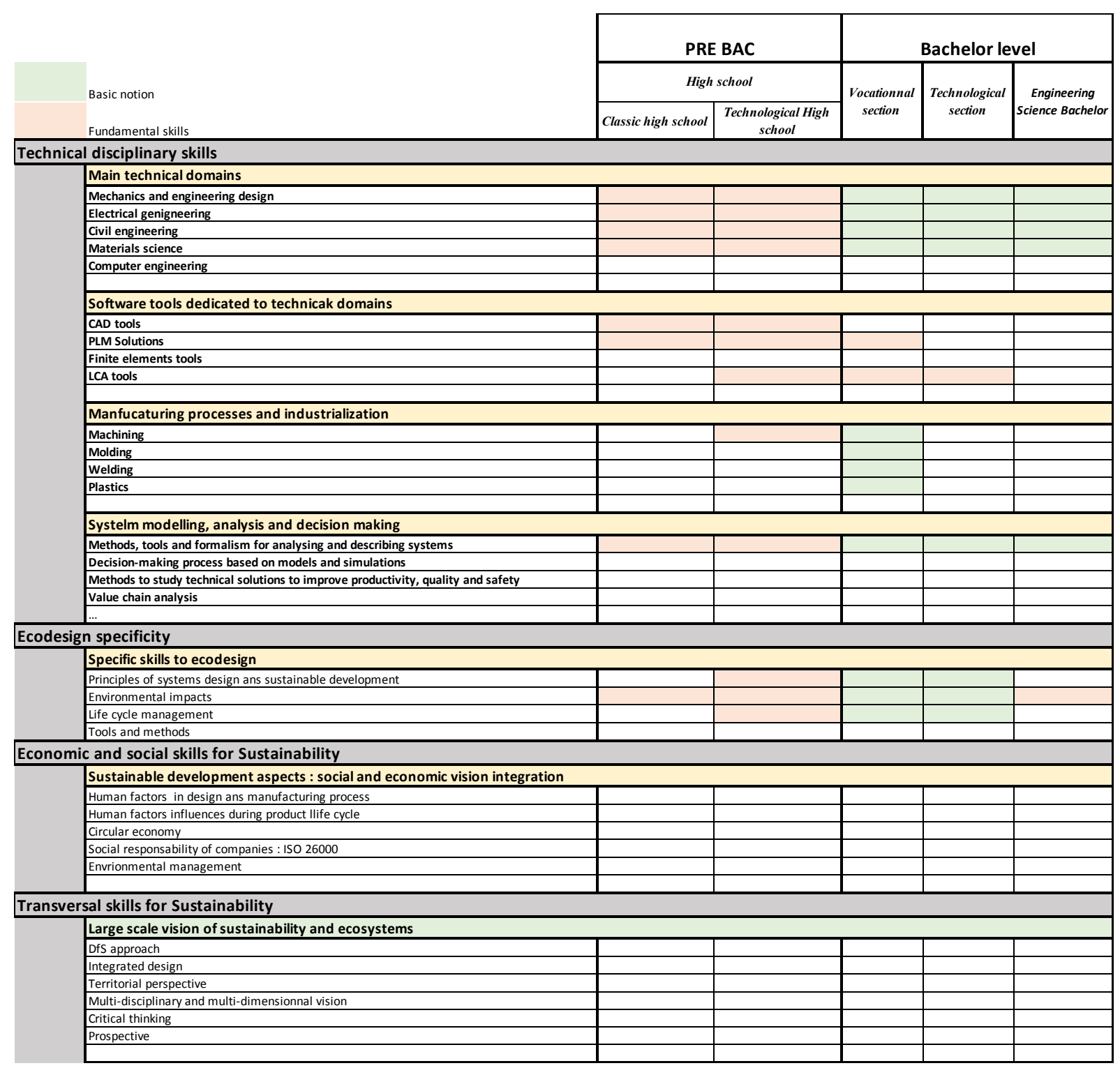

To complete this grid, we have also to evaluate teaching approaches in order to propose at teachers other educating methods. We have to bring students at the highest level of intellectual development according to Felder and Brent (2004):

- Possess the scepticism and inclination to challenge what is currently known;

- Question the assumptions underlying all accepted wisdom;

- Are reluctant to accept the first reasonable explanation;

- Employ both logic and intuition;

- Avoid transferring judgments made in one situation to another situation without critical evaluation. 
To achieve skills mentioned above, teachers must use active pedagogy and agree to step out of their comfort zone. It's important to change our education practice because students change and if skills evolve, basic knowledges are still present but nowadays the knowledge's access is everywhere and teachers must also evolve with that. So the next question is about engineering and technological curricula, do we propose an adaptation of the current curricula or do we define or redefine a real curricula which integrates the sustainability objectives?

\section{CONCLUSION}

The principle of the continuum of knowledge on different education levels and programs is difficult to envisage because the training paths of the students are very varied and depend on different training policies in France. However, the notion of continuum deserves to be deepened and refined on the axis of competencies. The following steps of the research will consist of different interviews with the professors in Bachelor and Masters of Science and Engineering School as well as with professionals in companies to identify which tools and methods can be used to carry out a rapid diagnosis of required knowledges and skills for students. This diagnosis will then offer them a training path that will lead them to an integrated, comprehensive and eco-design-relevant training that will allow them to take into account all the industrial issues related to the environmental transition.

\section{REFERENCES}

Andrews, D. and Soares, S. (2017), "Growing Spaces: developing a sustainability literate graduate”, Paper presented at Building Community: Design Education for a Sustainable Future: 19th International Conference on Engineering and Product Design Education, Oslo, Norway, 7 - 8 September 2017. London South Bank University.

Aoudia, M. and Abu Al-Qahsi, D. A. D. (2015), "Development of a new curriculum for an industrial engineering program that meets the curriculum requirements of ABET and the institution", IEEE Global Engineering Education Conference, EDUCON, 2015, pp. 151-158. https://doi.org/10.1109/EDUCON.2015.7095965.

Bhamra, T. A. (2004), "Ecodesign: The search for new strategies in product development. Proceedings of the Institution of Mechanical Engineers", Part B: Journal of Engineering Manufacture, Vol. 218 No. 5, pp. 557-569. https://doi.org/10.1177/095440540421800509.

Bergeå, O., Karlsson, R., Hedlund-Åström, A., Jacobsson, P. and Luttropp, C. (2006), "Education for sustainability as a transformative learning process: a pedagogical experiment in EcoDesign doctoral education", Journal of Cleaner Production, Vol. 14 No. 15-16, pp. 1431-1442.

https://doi.org/10.1016/J.JCLEPRO.2005.11.020

Boks, C. (2006), "The soft side of ecodesign”, Journal of Cleaner Production, Vol. 14 No. 15-16, pp. 13461356. https://doi.org/10.1016/j.jclepro.2005.11.015

Brones, F. A., de Carvalho, M. M. and de Zancul, E.S. (2017), "Reviews, action and learning on change management for ecodesign transition", Journal of Cleaner Production, Vol. 142, pp. 8-22. https://doi.org/10.1016/j.jclepro.2016.09.009

Cassais, M., H.C. and R.A. (2012), "Sustainability Curricula in Design", In International Conference on Engineering and Product Design Education, 6-7 September 2012, Artesis Universty College, Antwerp, Belgium.

De Vere, I., Melles, G. and Kapoor, A. (2010), "Product design engineering - a global education trend in multidisciplinary training for creative product design", European Journal of Engineering Education, Vol. 35 No. 1, pp. 33-43. https://doi.org/10.1080/03043790903312154

Dekoninck, E. A., Domingo, L., O'Hare, J. A., Pigosso, D. C. A., Reyes, T. and Troussier, N. (2016), "Defining the challenges for ecodesign implementation in companies: Development and consolidation of a framework", Journal of Cleaner Production, Vol. 135, pp. 410-425. https://doi.org/10.1016/j.jclepro.2016.06.045

Felder R-M and Brent, R. (2004a), "The intellectual development of science and engineering students", Part1: Models and challenges, Journal of Engineering Education, Vol. 93 No. 4, pp. $269-277$.

Hanning, A., Priem Abelsson, A., Lundqvist, U. and Svanström, M. (2012), “Are we educating engineers for sustainability?” International Journal of Sustainability in Higher Education, Vol. 13 No. 3, pp. 305-320. https://doi.org/10.1108/14676371211242607

Harris, K. S. and Rogers, G. E. (2008), "Soft Skills in the Technology Education Classroom: What Do Students Need", Technology Teacher, Vol. 68 No. 3, pp. 19-25.

ISO (2011), "ISO 14006:2011", Environmental management systems - Guidelines for incorporating ecodesign

Kamp, A. (2017), "Engineering Education in the Rapidly Changing World: Rethinking the Vision for Higher engineering Education. TU Delft, Faculty of Aerospace Engineering”, ISBN 978-94-6186-609-7. http://resolver.tudelft.nl/uuid:ae3b30e3-5380-4a07-afb5-dafd30b7b433 
McAloone, T.C. and Pigosso, D.C.A. (2017), "From Ecodesign to Sustainable Product/Service-Systems: A Journey Through Research Contributions over Recent Decades”, In: Stark, R., Seliger, G., Bonvoisin, J. (eds) Sustainable Manufacturing. Sustainable Production, Life Cycle Engineering and Management. Springer, Cham.

Olsen, S. I., Fantke, P., Laurent, A., Birkved, M., Bey, N. and Hauschild, M. Z. (2018), "Sustainability and LCA in Engineering Education - A Course Curriculum”, Procedia CIRP, Vol. 69 No. May, pp. 627-632. https://doi.org/10.1016/j.procir.2017.11.114

Pargman, D. and Eriksson, E. (2015), ““'It’s not fair!” - making students engage in sustainability”, Sixth International Conference on Engineering Education for Sustainable Development 2013: Rethinking the Engineer, Cambridge, UK, 22-25 September 2013, (September 2013), pp. 1-11.

Pérez-Foguet, A. and Lazzarini, B. (2019), "Continuing professional education in engineering faculties: Transversal integration of sustainable human development in basic engineering sciences courses", Journal of Cleaner Production, Vol. 218, pp. 772-781. https://doi.org/10.1016/j.jclepro.2019.02.054

Perpignan, C., Robin, V. and Eynard, B. (2018), "From Ecodesign to DFS in engineering education", In DS 93: Proceedings of the 20th International Conference on Engineering and Product Design Education (E\&PDE 2018), Dyson School of Engineering, Imperial College, London. 6th-7th September 2018, pp. 622-627.

Pezeshki, C., Panchal, JH and Ameta, G. (2012), "Blueprints for Teaching Ecodesign and Sustainability to University Students", In Kaufmann, J., Lee. KM. editors. Handbook of sustainable engineering. Dordrecht: Science+Business Media. pp. 7-30.

Roberts, A. (2012), “A justification for STEM education”, Technology and engineering teacher, Vol. 71 No. 8 , pp. 1-4. https://doi.org/10.1126/science.1201783

Segalàs, J., Mulder, K. F. and Ferrer-Balas, D. (2012), "What do EESD "experts" think sustainability is? Which pedagogy is suitable to learn it?: Results from interviews and Cmaps analysis gathered at EESD 2008", International Journal of Sustainability in Higher Education, Vol. 13 No. 3, pp. 293-304. https://doi.org/10.1108/14676371211242599

Svanström, M., Palme, U., Wedel, M. K., Carlson, O., Nyström, T. and Edén, M. (2012), "Embedding of ESD in engineering education: Experiences from Chalmers University of Technology", International Journal of Sustainability in Higher Education, Vol. 13 No. 3, pp. 279-292. https://doi.org/10.1108/14676371211242580

Vallet, F., Millet, D., Eynard, B., Glatard-Mahut ,S., Tyl, B. and Bertoluci, G. (2013), “Using eco-design tools: An overview of experts' practice", Design Studies, vol. 34, no 1, pp. 345-377, https://dx.doi.org/10.1016/j.destud.2012.10.001

Vezzoli, C., Ceschin, F., Diehl, J. C. and Kohtala, C. (2015), "New design challenges to widely implement "Sustainable Product-Service Systems"“. Journal of Cleaner Production, Vol. 97, pp. 1-12. https://doi.org/10.1016/j.jclepro.2015.02.061

Wiek, A., Withycombe, L. and Redman, C. L. (2011), "Key competencies in sustainability: A reference framework for academic program development", Sustainability Science, Vol. 6 No. 2, pp. 203-218. https://doi.org/10.1007/s11625-011-0132 